\title{
Meetings
}

\section{Members' Page}

All meetings are held in the Zoo Meeting Rooms, Regent's Park, at 6pm. Tickets for the meetings only are free, for wine and cheese supper $£ 3$; both are obtainable from the FPS office (an SAE would be appreciated).

Thursday, February 21: John Burton, Executive Secretary and Chairman of IUCN's wildlife trade monitoring group, TRAFFIC, will discuss the group's problems and achievements, followed by a short film, 'Problems of Conservation'. After a wine and cheese supper Jane Thornback will talk about of her work as compiler of IUCN's Mammal Red Data Book. Another short film, 'Wildlife in Danger', narrated by FPS Chairman Sir Peter Scott, will be shown.

Tuesday, March 18: Grenville Lucas, Deputy Keeper of the Herbarium at the Royal Botanical Gardens, Kew, will describe the work of IUCN's Threatened Plants Committee, of which he is Secretary. A wine and cheese supper will be followed by a film on endangered plants.

\section{Cambridge Meeting and Excursion to Ouse Washes}

Saturday, March 1: FPS and the Cambridgeshire and Isle of Ely Naturalists' Trust will hold a joint meeting, chaired by the Earl of Cranbrook, on 'Reserves and Their Management', at $7 \mathrm{pm}$ in the Main Lecture Theatre of the Department of Anatomy, Downing Street, Cambridge. Speakers will be $M$. Massey of the Naturalists' Trust, on reserves in East Anglia and Wales, and Dr Keith Eltringham, FPS Council member, on East African reserves. A wine and cheese supper will be followed by two films, 'The Woodmen and the Wild' and 'At the Crossroads'. Tickets, $£ 2.50$, are required only for the supper, and only 80 can be sold. Please order in advance from the FPS office; an SAE would be appreciated.

A guided tour to the Ouse Washes will be conducted earlier in the day. Please contact the FPS office for details.

\section{'Oryx' Index}

The index for Volume XIV, 1977-78 (four issues), will be available on January 1. Members who would like their copies bound (cost $£ 7$ including postage) should send them to the FPS office by that date. Spare copies of individual issues can be supplied.

\section{Oryx Tours 1980}

Zambia and Botswana, August 9-31: Three days at Musungwa Lodge in Zambia's Kafue National Park, with daily viewing, by Land Rover or boat, of the park's enormous variety of game, including lion, eland, sable, roan, impala, wildebeest, hartebeest, oribi, puku and lechwe; a day at Victoria Falls; and a week each at Norman Carr's Chibembe Safari Camp near South Luangwa National Park and the seldom-visited Okavango Delta in Botswana. The leader is Dr David Jenkins, Head of Station at the Institute of Terrestrial Ecology.

Madagascar, Réunion and Mauritius, November 17-December 7: Three weeks viewing the many forms of wildlife unique to these Indian Ocean islands. The leader is Dr Alison Jolly, an authority on lemurs and author of Lemur Behaviour. 